Journal of Islamic Studies and Culture

June 2016, Vol. 4, No. 1, pp. 115-126

ISSN: 2333-5904 (Print), 2333-5912 (O nline)

Copyright (C) The Author(s). All Rights Reserved.

Published by American Research Institute for Policy D evelopment

DOI: $10.15640 /$ jisc.v4n1a14

URL: https:/ / doi.org/ 10.15640/ jisc.v4n1a14

\title{
Moderate Muslim: Mapping the Ideology of Mass Islamic Organizationsin Indonesia
}

\author{
Sangkot Sirait ${ }^{1}$
}

\begin{abstract}
Indonesia is rich with religious traditions, and the people show their various religious attitudes to respond their problems in unique ways based on factors, such as education backgrounds, family, customs, and religious environment. When Islam entered Indonesia, adherents of various religions did not notice their difference, nor do they accentuate their identityies. Difference is not important to talk about, and the main one is that they can live in harmony.It means, dinferences in religious understandingoes not have mucheffects on their lives. Lately, we see something different. Apperson's identity or a community's religious attitude is the first thing to consider. A community is characterized by their activities of such circumstances: religious, social, and political, and these are in parallel their religious attitudes: radical, liberal, and moderate. Other groups also demonstrate different activities, such asSufism or thariqat, but they did not possess certain characteristics.Ttheir attitudes are moderate. Thee paper provides general description on moderate Muslim and observes how this community dominates the religious models and attitudes in Indonesia. In addition, the paper describes factors that help the community survive and deal with radical and liberal groups.
\end{abstract}

Key words: attitude, moderate, radical, liberal, movement, religion, tradition.

\section{Background}

No religion revealed by God without being surrounded by a variety of cultures.Turner states, "Religion as an expression of the social forms of human communities inevitably changes with major changes in society" (2011). Islam is a religion that was originally revealed in an uncivilized society. Basically, Islam is neutral. Its teachingsare based on the Holy Book. Normatively, no difference is in the teachings of any religion, but humans' responses to the teachings led to various understandings and attitudes. In the history of Islam, three attitudes appeared to be related to the responses, i.e., radical, liberal, and moderate. In Islam, radicalism can be found in the madhhab (school of thought) called Khavarij; Islamic liberalism is found in school of MutazilahWestem historians have characterized the Mutazilah as rasionalist and as heterodox thelogian; and moderate Islam can be seen in the religious attitude of Ashan followers, namely Ahl al-Sunnahwa'l-Jama'ah

Khawarij (the secessionist), initially this group followed 'Ali, but he when allowed an arbitration following the battle between him and Mu'awiyahin 657 at Shiffin they protested and 'seceded' from the party of 'Ali. The Khamanij rejected the Sumi view that the rule must belong to the trib of Quraish as well as the Shi'i claim that he must be a descendant of the Prophet. Instead, they had the right action and faith are the only essential attributes of a true Muslim, including a leader among them. Thus they viewed the caliph as a virtuous authority of Islam, who called for jihad and tried to kill whoever they regarded as being outside their egalitarian community. The Mutazilah among the earliest group of thinkers identified by their rasionalist approach to Islamic doctrines. The Mutazilah recognize a power in the human agent that makes her/ him responsible for acts performed.

1D r. Sangkot Sirait, Lecturer atFaculty ofIslamic E ducation, State Islamic University Sunan Kalijaga, Yogyakarta, Indonesia. e-mail: sangkot_sirait@yahoo.co.id. 
In this sense, human action is different from all other events. They held that only by asserting human freedom can one justify God's power to blame or to punish man. They ageed that pesson sintuitivdy are sedf-consiaus of their capadity to make dhices and that this consiaus avareness and intention will make pesans responsible for the atcome of their ads(Martin at al.,1997).

Ahl al-Sumnah wa'l-Jama'ahasa school of classical Sumi thought led by Abual-Hasanal- Ashari(d.935) was one of the pioneers of occasionalism which deficts the world as a series of occasions that are effects of God's will. He rejects rationalist ethics and holds that man is incapable of understanding the logic of good and evil because these are derived from G od (TheOxfordEngdqpeela of theModem IdamicWodd, 1995).

Today these models of Islamic thoughts can appearwith different names. Radicalism is represented by groups, such as Islamic D efenders Front (Forum Pembela Islam), Communication Forum of the Followers of the Summanand the Community of the Prophet, Laskar Jihad, and Indonesian Mujahidin Council (Firman Noor, 2017). Liberalism is represented by Liberal Islam Network (Jaringan Islam Liberal-JIL), and Moderate Islam is represented by Nahdhat alUlama'(NU) and Muhammadyah An interesting aspect of those three attitudes is that most of Indonesian Muslims are moderate. Moderate herein means believing in Quran and Hadithas the principles of their life and that anarchy will not be found in responding various differences and cultures, as well as preaching attitudes. Other attitudes are possessedby Indonesian Muslims, but moderate is the highest in number. Thus, the question is why moderate Islam dominates the attitude of Indonesian Muslims and how they react to other attitudes, such asliberal, and radical Islam?

\section{Religious Attitude}

Religious attitude is an expression of a person's faith in his God and His teachings. It becomes the base of the person's deeds. Religious deeds are not mere activities. Indeed, some strategies are applied especially in encouraging Muslims to practice their religion appropriately. In the context of Islamic movement, three strategies are employed by moderate Muslims: structural, cultural, and social mobility. Structural strategy takes the form of political strategy for it utilizes political means, such as occupying the legislative position, the House of Representatives, and the People's Consultative Assembly. Also, the people may influence the legislative duties by monitoring the bureaucracy and Indonesian National Armed Forces (ABRI) (Kuntowijoyo, 1996).

Next, structural strategy is an attempt to influence social behaviorsand perspectives. The former is practiced through persuasive preaching, dialogue, lobbying, and mass media. However, no exclusivity in employing one strategy is applied. An organization may sometimesuse more than one strategy. The principle in cultural strategy is religion as a moral force and inspirational (moral, ethics, and intellectual). In the sense of moral force, religion does not put any force on anyone. Instead, the urge should come from within the person himself. Social mobility is different from the previous strategies in a way that it emphasizes more on the aspect of changes by improving human resources through education. Bahtiar Effendi puts another aspect adding to these three that is infrastructure, which contributes to the harmonious relationships between the people and the government (Bahtiar Effendy, 2003).

Deed is the realization of a believed value system. Manyfactors influencee a person's religious attitude. In this paper the thesis that can be raised is the development of moderat Muslim in Indonesia is due to cultural factors, the strength of the governement and educational institutions.

\section{Linkage between Religion and Culture}

Culture is an art, value, or norm, as well as symbol of daily life. D espite the fact that culture pays attention to the tradition and social reproduction, it is also a creativity and change. Chris Barker states that the concept of culture is more anthropological because it focuses on daily meaning, value (abstract idea), norm (principle or strict rule), and material symbols. Meaning is determined not individually but collectively. Thus, cultural ideas refer to the meaning owned collectively (2000). To say that two people become part of a similar culture means that they view the world in the same way and can express their selves, thoughts, and feelings about the world in a way that can be understood by each other. Thus culture depends on the interpretation of participants upon what happened around them, and how they understand the world in a similar way (Hall, 1997).

Skinner, as quoted by Hall in Theries of Personality, states environment (including culture) highly influences an individual's personality (Hall and Lindzey, 1978). 
It is a pattern of consistent behavior reflecting reinforcement that is experienced by the person. Culture provides some color on a person's experience in a community. It is aguide for the person's behavior upon various issues, including religion.

Generally, Western scientists hold the theory that the first messengers of Islam in the Archipelago were Muslim traders who brought their religion along with their commodities. In this way, Islam entered Indonesia through trading activities (Turner, 2011). An elaboration of this theory states the traders married local women. The establishment of new Muslim families, which was a community nucleus, played a big role in spreading Islam. The interactions among Arabic, Indian, and Persian cultures were evident when Islam come to the archipelago and interacted with the Javanese culture. Animism-dynamism religion that was the root of Indonesian culture was so flexible that it could survive within the influence of Islamic culture.

The entrance of Islam has an implication on a new dynamic related to religious-social life of the people, as well as on the cultural and scientific treasures. Cultural assimilation resulted from conflicts and accommodation. It resulted in various Islam, which was then called local Islam and thus was different from Islam in other areas of great tradition. Current rresearch positively appreciated that any articulation of Islam in certain areas would be different between one andanother. Therefore, the symptoms were humans' creations in understanding and interpreting Islam according to their own culture, as well as in contributing to the mosaic of Islamic culture.

Indonesia is an archipelago nation. It consists of over 1,000 islands and any more that are uninhabited. Of these, the most widely known are Sumatra, Java, Bali, Borneo, the moluccasand and the celebes. These islands enclose a kind of eastern Aegean; they abound in coves and estuaries and furnish numerous potential harbor sites for ships plying the trade routes between the Indian O cean and the South China Sea (Johns, 1987).

Indonesia is a country rich in culture. Culture is the first aspect that forms the community value system long before religion. Indeed, it is the flesh and blood of the people and they live with it. Religion and religious attitude come after it. Generally, Islam in Indonesia has been wrapped in culture, despite the fact that Muhammadiyah has recently tried to separate religion and culture. Muhammadiyah is known to be the modern Islamic organization in Indonesia. However, the organization is lenient in facing foreign traditions. In the aspect of theology, Muhammadyahis moderate that makes changes revolutionarily, such us traditions perceived as tahayyul (superstition), bidah(heresy), and khurafat(fable)which exist whitin the Moslem community, while its counterpart, Nahdhat al-Ulama, do things evolutionarily.

Benedict, as quoted by Daniel L. Pals (1996) states that culture is the key to understand individual's personality. While working in the field, he acknowledged differences in the personality of Indian Pueblo, which are calm and loving, with the tribe of Pima and Kwakiutl, which is uncivilized. The difference in the fundamental characteristics of Pueblo culture emphasizes harmony, which does not exist in other tribes. Benedict viewsculture as a pattern, a kind of "collective personality" that is learned by each member.

In the context of Indonesian Muslim, harmonyy exists in the characteristics of most people. They adapt to the environment and culture, as well as the nature. Geertz, as quoted by Daniel, asserts that Islam in Indonesia is different from Islam in Marocco. The difference is the result of different environment. Most Indonesians live as farmersinrice plants, while Maroccans live as shepherds indeserts. They are also hard workers. Living in farms has been the tradition of most Indonesians. Such characteristics are parts of Hinduism and Buddhism teachings, emphasizing meditation, inwardness, and self-serenity. It was inthe 1300s that Islam come into the archipelago through trade and mingled with the values of Hinduism, Buddhism, and animism held by previous farmers. Thus, Indonesian Islam developed flexible characteristics, such as adaptive, pragmatic, and gradual. The condition is different from the Maroccans, who are rigid, uncompromising, and aggressive. Islam in Indonesia develops in gradual, liberal, and accommodative situations, while Islam in Marocco isstrict, puritan, and uncompromising.

\section{Islamic Culture in Indonesia}

Different from other religions, Islam was introduced toIndonesias in a flexible way. Many ancients Indonesian mosques took the form of local buildings, which were the heritage of Hindu's culture. It was different with Christianswho built their churches assembling Western architecture. 
Buddha, as well as Hindu, entered Indonesia bringing theirmandalas and stupas. Meanwhile, Islam did not bring Arab cultural symbols. This shows that Islam is more tolerant towards local culture.

Recently, Indonesianshave adopted the form of the dome for the mosque. Thus, it is evident that Islam is not anti-culture. All elements of culture can be adopted in Islam. The influence on Indian architecture could be clearly found in the building of mosques. It was similar with Mediterranean architecture (K untowijoyo, 1994). Than come a new development; of the culture of the urban, it isintroduced by traders and highly mobile middle class. But Islam that was spread in the rural areas became static and immobile. In this sense, Islam in Indonesia was indigenous, "pribumi." In other words, Islam in Indonesia experienced a kind of indigenezing (pribumisas). It was evident in art. Middle East arts reflect mobile and active spirits, represented in their full, lively, and vibrant calligraphy. When it entered Indonesia, the expression changed. Compare Arabic music (if we can call it Islamic music) with Indonesian Sunan Kalijaga's version of gamdan sdkaten to celebrate the birth of the Prophet. The former sounds lively and has rapid and dynamic beats; while the latter is more calm and slow. In gamdan the element of tranquility - not only the sound becomes an integral part of music.

Thus, from dynamics in form, the music became more contemplative and mystics when it entered this nation. So, the culture of urban, merchant, and middle class which were mobile and dynamics turned into the culture of rural, which was agrarian and static. In the aspect of teaching, Islam has never wholly experienced "javanisation." However, the expression of Muslim religiosity in Java was characterized by peace, unaggressive, and tranquil.

\section{Institutions of Education and Religious Institutions}

Educational and religious institutionsaffected behavior because they insert the basic concepts of moral in every individual. The understanding good and bad, the border between what is allowed andwhat is not allowed, are obtained from education and the teachings of religion. The concepts of moral and religious teachings have some bearing on the system of beliefs. It is not surprising that, in turn, the concepts play important roles in changing people's behavior towards certain deeds. Upon a controversy, people generally try to find information to strengthen their attitudes. Also, they do not take partiality. In that case, moral teachings obtained from education or religious institution becomes a single determinant.

Historically, pesantren has been known to be an accommodative institution for local cultures with their principles of being fair, non-extreme, argumentative, balanced, consistent, and tolerant. It has to be admitted that there have recently been generalization about peantren According to Abdur Rahman Mas'ud, the radical pesantrens though smaller in numbers, are generally "imported" from other countries and they put on textual-scriptural school of thoughts. The radicalism is influenced by the thoughts of Sayjid KutbandHassan al-Banna, who based their believes on Islamic fundamental movements of ImamAh\}mad Iln Hambal and Iln Taymiya. Acculturation of pesantren culture with local culture is a negotiation process between tradition and Islam and thereby forming a new culture of pesantren It has been evidenced that Islam never places itself in opposition against local culture. Moderate Indonesian Muslims are generally those who obtained good education in pesartren As written by Horikoshim, pesantrenhas got the power from the kyai or 'ulama', rooted in moral credibility and ability to maintain social institution (Horikoshim, 1987).

Residents of pesantrenare known to be traditionalists and are accommodative towards local culture. In spite of the facts that they, together with modernists santr (students), tried to find their true identity, plunge themselves in abangan culture. Pesantrenis a favorable place for the development of culture and Islamic civilization. Compromisesing towards local culture is considered by the non-pesantren people, such as radical Muslim believing in textual thoughts, to be permissive, vague, and bidah Meanwhile, according to kyai(title of a religious leader) and santri(religious pupil), the attitude is a choice and an approach to spread Islam through culturewhich is accepted as long as it is based on noble character. Most of moderate Muslim is the educated or those who are learning Islam in formal institutions and pesantrens Therefore, their insights on Islam allow them to understand Islam comprehensively, either theology orhistory. In fact, Liberal Islamic Community is closely related to moderate community. It is because most of the members are the alumni of religious education institutions, such as peantren and Muhammadiyahinstitutions.

Apart from moderate community, Islamic radicalists learned Islam not through Islamic institutions,like pesantrens and madrasahs but through religious movements and exclusive teachings in informal education, such as group studies on campus and mosques. Strategies used by radical Islamists are different from those of moderate. Almost all elements of education systems, such as materials, methods, approaches, textbooks, are different, betweenmoderate Muslim andradical groups. 


\section{Moderate Muslim and the Govemment}

The majority of Indonesians are Muslim. Islam was peacefully spread in all parts of Indonesiafor centuries ago. Indonesia's struggle in obtaining its independence in 1945 brought about religious harmony, which was stated in the ideology so-called, Pancasila, and the 1945 Constitution. Muslim leaders played an important role in accepting Pancasila as the state ideology. Pancasilais the official philosophical foundation of the Indonesian state. Pancasila consists of two Old Javanese words (originally from Sanskrit), "paña" meaning five, and "silla" meaning principles. It comprises five principles held to be inseparable and interrelated: 1. Belief in the one and only God; 2. Just and humanity; 3. The unity of Indonesia; 4 . Democracy guided by the inner wisdom in the unanimity arising out of deliberations amongst representatives; 5 . Social justice for all of the people of Indonesia.

Given the history of Pancasila, on June 22, 1945, the Investigating Committee for Preparatory Work for Indonesian Independence (BPUPKI) has received the draft suggested by the Muslims for the Preamble of the Constitution. The Jakarta Charter states that Indonesia is a nation based on "D eity with the obligation of carrying out Islamic shar'aby the adherents". The Jakarta Charter is a political matter. It is a historical documentthat inspires the Preamble of the 1945 Constitution. Jakarta Charteris a document which it was hoped would comment wide enough acceptance to serve as a preamble to a constitution. It is also a political compromise between the Islamic and nasionalist blocs in Investigating Committee for Preparatory Work for Indonesian Independence (BPUPKI) to mediate conflics between in religion and state(Mujiburrahman 2006).

It was then changed. On August 18, 1945, a day after iindependence, the draft of the Constitution, including Jakarta Charter, was discussed in the special committee. In the morning of that day, a Japanese official brought several Christian leaders from Eastern Indonesian regions to meet the Vice President, Mohammad Hatta. The Christian leaders objected the draft, especially the seven words in the Jakarta Charter text and the requirement that the Indonesian President should be a Muslim. They insisted that the Constitution should treat all communities equally. Moreover, the Constitution should maintain the unity of national plurality.

As a pious Muslim, Hatta called Muslim leaders to discuss the political aspiration of the Christian leaders. He convinced the leaders that accepting the aspiration can maintain national unity regardless of different religious adherents. The Islamic leaders agreed to remove the words after "Keuhanan" that specifically required Muslim adherents to practice Islamic shan'a in their daily life. The words were replaced by "Yang Maha Esa". Rather than imposing Islam as the state ideology, the majority of Moslems chose Pancasila, where all religions are free to practice what they believe and are treated equally. Not only accepting Pancasila, Muslim leaders also agreed to remove the phrase that the Indonesian President should be a Moslem. The agreement was formally signed on August 18, 1945, the day of the Constitution became effective (Tarmizi Taher, 1998).

Nahdhat al-Ulama' (NU) is the first Islamic organization that confesses Pancasaila as the single base of state. Even, As'ad Syamsul as a charismatic figure of NU said that 'each Indonesian Muslim required or obliged to confess it and unlawful to refuse it. It is because of the first principle of Pancasila does not conflict with the first Islamic doctrin that 'no God but Allah'. Indeed, there are various reasons why NU accepted Pancasila, among others NU wants to coexist and comportable with governemant,so as at $1980 \mathrm{New}$ Ordre forced the officials of NU to make decision whether heis opposition or accommodation clearly. Soeharto as president said to confess different ideologies besides Pancasila is similar to be dissident or subversion (Aminudin, 1999).

The political views of Muhammadyah on issues of the single base ispropose given confirmation that Pancasila is not a religion and religion are not politicized as of Pancasila. Then, Desember 1985 Muhammadyahformally accept Pancasila as the principle of organization without turmoil (Aminudin, 1999). Easly the reception is not separated from the role Amin Rais as a moderat Muslim and Muhammadyahintellectual who see Islam over ideology. For him, Islam and Pancasila are at their respective positions. Islam is the category of revelation and Pancasila as the ideologyof human creation. Therefore Muslims could easly accept Pancasila as a society and a state ideology. "The interaction of Islam and politics has been an integral part of the Indonesian experience since the Muslim kingdoms eras in the seventeenth century. Their nexus has beeninexorably linked with the idea of an Islamic state. However, the actual vitality of this idea is still unclier. 
Given the fact thatthe mostvisible character of an Islamic state is formal implementation of sharia, the interrelation between Islam and politics depends much on the extent to which shar'a is complemented by the state" (Arskal and Azra, 2003). Islamization in this area is an ongoing process that influences the Indonesian Muslims. The Dutch Colonial Governments in South East Asia named Islam in several areas, such as Javanese Islam, Sundanese Islam, Minangkabau Islam, Aceh Islam, Bugis Islam, or Malay Islam. Now, 'ulama' in this areas state there is only one Islam, and the adherents are united as sumi following the mazhab of Shafi'i. Their cultural expressions are numerous; with regard their ethnical and cultural backgrounds. In fact, their cultures are influenced by Islamic culture.

Since the New O rder (1968-1998), the educated and middle class students from pesantrens has appeared to fill the 'vacuum' in Islamic political leadership. The growth of Muslim intellectuals becomesan important phenomena at this time. Governmental policyies that provide them wider spaces to obtain education. It was different from the educational policies in the colonial erasin which only children of aristocrats and noble families could obtain education. Similarly, Christian/ Catholic children educations weregiven by the church. Muslim students had limited access topesantrens and madrasahs (Gaffar,1993). The success of new Muslim intellectuals was achieved in the 1970s. They were employed as administrators of the government and lecturers at universities under the patronage of their seniors. The explosion of educated students encouraged the mobility of Muslim students (santri) both vertically and horizontally. Horizontal mobility could be seen in the spread of profession achieved by the students in many sectors. While vertical mobility was evident in the employment of students in the government or a more modern structure (Anwar, 1992).

Massive absorption of educated santri in the government agencies, academic institution, and various socialorganizations have giventhemopportunities that can only be obtained by non-santri (Fachry Ali, 1991). Santri, who were employed in modern institutions, are mostly activists who deeply observed their strategic positions through patronage. Meanwhile, other recruited santri improved their positions because they were alumni and joined student organizations based on loyalty towards the Islamic communities (Mahasin,1993). The phenomenaappeared in the 1980s are known as the syndrome of Islamization of bureaucracy which blurred the dichotomy of santri-priyayi (student-noble) formulated by Geertz (Anwar, 1992). In addition, Suharto's interest on mysticism keeps continuing. However, there was a shift on it. Among his consultants on mysticism was Zahid Husein, the most influential figure. In the 1990s, Zahid Husein encouraged Javanese mysticism to identify itself with Islam and be apart from Christian (Hefner, 1995).

Complementarities between the government and moderate Islam community also appear in the government appreciation towards local Islamic cultures, which were supported by the moderate Muslim. The role of Q asim Nurseha in the Islamization of Soeharto family almost became common perception, especially when tahlil(readings are Islamic religious rites are wrapped with culture) were echoed in the funeral of Tien Soeharto in1996 (Aminudin, 1999). Tahlil, as performed in the procession, is clearly the cultural pattern of moderate Islam and becomes its trademark, which is not found in other Islamic communities.

Almost of all Indonesian Muslims are Sunni and follow the mazhab of Shafi'i. Islambrought by South Asian and Arabic traders, as well as Sufis in the 13th century. There was a rapid growth in the 15th and 16th century and in the 18th thatmost population of Java and Sumatera embraced Islam. Because of sufism, mysticism becomes an important part in Indonesian Islam (Hodgson, 1975). Religious orientation has made Islamtake the symbol and metaphor of local culture. As a result, Indonesian Islam becomes tough, syncretic, colorful, and multi-layered. The expressions were mingled in harmony with the structure of Javanese culture. The powerful men and farmers absorbed the concept and practices of Islam into Indian pantheism and animism. Middle class traders took Middle East and South East Islam as the results of their trading activities. Thus, their Islam became doctrinaire and puritan (G eertz,1968).

Having influenced by the culture, contemporary Islamdeveloped two firm traditions. Bothare represented by two mass organizations. Sufism, or popular Islam, which dominates the rurals and pesantrens is represented byNahdhat al-'Ulama', while scriptural-modern Islam, which dominates the urbans, is represented by Muhammadyah Islamic experts, such as thekyais become the symbol of Sufism, while intellectual Muslims dominate the activities of Muhammadyah 
Muhammadyahis considered to have met the requirements to develop masyarakat madani (civil society) because Muhammadyahhas receivedpower through social mobility, economy, education, as well as great exposure towards mass media. However, it has to be admitted that Muhammadiyahis not the first organization introducing the idea of civilsociety. Indeed, Muhammadiyah's realization towards the idea was considered late compared to their counterpart, Nahdhat al-Ulama'as traditionalis in socio-religious activities. In spite of the fact that it's base are the ruralsand pesantrens, Nahdhat al-'Ulama'was the first to introduce the idea of civil society in the 1980s (Effendi, 2001).

Formal Islamic groups, such as Hizbut Tahir Indonesia (HTI), Partai Keadilan Sejahtera (PKS),Majeis Mujahidn Indonesia (MMI), and the generations of Islamic State of Indonesia (NII), have fought for a great framework for an Islamic-base state. Nahdhat al-Ulama'does not conform to the idea of the Islamic state because it has accepted Pancasila and the Republic of Indonesia as the final ideology and form of Indonesia (Ridwan2009). Although it is still unclear on how this organization contributes to the civil society, the concept of a state and how it will be developed have made the families of Nahdhat al-'Ulama', both in the urban and the rural areas, as well as in Pesantrens or Non-G overnmental O rganizations aware of the importance of civil society and its adaption to develop a democratic Indonesia.

Since the 1970s, there had been new generations of thinkers and activists in Indonesian Islam. At the beginning, they were genealogically related to or inspired by Masyumi and Muhammadiyah initiating the new way of thinking. Among them was Nurcholish Madjid, Ahmad Wahib, Djohan Effendi, M. Dawam Rahardjo, Tawang Alun, Sudjoko Prasodjo, or Adi Sasono. Their main objetives were to represent Islam that meet the needs of Islamic community, such as social, economy, and politics. They did not reflect certain ideology but wanted Islam and the stateexist harmoniously and peacefully.

Overtime, several young figures ofNahdhat al-Ulama' following Abdurrahman Wahid, such as Slamet Efendi Y usuf and Masdar F. Mas'udi was the followers of the new intellectual movement. The encounter of "modernist" and "traditionalist" was critical because the new movement not only was supported by young intellectuals but also was expected to solve the conflict that they both had ever had. Both modernists and traditionalists agree to represent Islam that is not ideological-exclusive, but Islam that is relevant to the needs of Islam in particular and Indonesia in general (Fachry Ali \& Effendi, 1986). A part from Islamic movements that carry revivalism, reformism, modernism, and fundamentalism (liberal Islam), one movement appeared, namely traditionalism (traditional Islam), which was called customary Islam by K urzman (1998). Customary Islam, the combination of traditionsand the customs of Islam, was the first tradition in the Islamic movement. The combination to some extent can be seen in the habitsranging from the ordinary peopleto highly respect, holy figures, magics, and sacred places. Customary Islam tends to be justified only in local terms, such as identity (this is the way "we" are doing), prudence (it cannot hurt to propitiate the powerful, be theirspirits or spirit-impused humans), and a linkage to the past (loyalty to one's teacher, or one's teachers' teacher) (Nasr, 1987); Graham, 1993).

The power of moderate Islam is not only theresult of internal efforts sought by the Moslems through their cultural understanding, but also of their support on politics. In the teachings of moderate Islam, politics is an inseparable part of Islam. Political struggle is religion. Given the fact, Allan Samson, as quoted by Aminudin (1999), believed that from all religions, Islam was the most perfect in its persistence and determination to directly link religion and politics. Muslim communities who intensely negotiated with the government to develop the country were those who were well educated in religion and morality.

This, however, did not mean that no conflict existed between the moderate Muslims and the government. Indeed, the issue was on the normative laws of the religion, or related to governmental policies. There was nothing found related to a coupdéat, not even to insist on the nation to be based on Islam. Aspects related to religion, for example, can be seen in March 1981 when Majelis Ulama Indonesia (the Ulama Council ofIndonesia) issued their fatwa on the prohibition for Moslems to join the celebration of the Christmas. Then in December 1985, the government decided to permit one foundation to hold a lottery called PORKAS or SD SB, which was hoped to help to fund sport's activities, especially football. Islamic Organization viewed the lottery as a kind of gamble, because people venture their life in it. Moreover, the places to hold the lottery cards were near schools and mosques. 
It was then understandable that the government wanted the modern Islam communities to cooperate with the government in developing the country. The government is obliged to support the Muslim communities. In this way, moderate Islam survived by the support of two powers, internal Muslims and the government. From the political aspect, NU and Muhammadiyahrarely getting pressure from the governement.Instead, the state would actively approach these two great organization.. The interest of state, particularly in social-religiousity and regulations, can run well on the support of two religious organizations. By doing so, the governement wiil no longer dare to impede the existence of the two organizations. this, indeed, it has facilitated.

In fact, in the Nahdhat al-'Ulama', an organization known asAhl al-Sumnah wa'l-Jama'ah in East Java, there isSalafiyah a community which can be found in several pesantrens The community has special meaning, that is "adherent of Imam Shafi'i for the Islamic jurisprudence, adherent of ImamAshai and Maturidi for the theology, and adherent of Imamal-Ghazali for the mysticism." Nahdhat al-'Ulama' attaches itself to Ahl al-Sumah wa'-Jama'ah which is in some way identical to Salafiyyah known as traditional community (Nashir, 2013).

The Salafiyah of modern Islam generally refers to the thought of Imam Ahmad ibn Hambal, Ilon Taymiya, Muhammad ibn'Abd al-Wahhab, Jamaluddn Al-Afghani, or Muhammad 'Abduh Rashid Rida'. Kyai Ahmad Dahlan, the founder of Muhammadiyah followed Ahl al-Summah wa'-Jama'ah because Muhammadiyah was considered identical to Salafiyah by traditional 'ulama', to the Shafi'iyahin their ritual practices, and to Imamal-Ghazali in their mysticism. After staying in Mecca and was introduced to a reformed way of thinking about Islam, Ahmad Dahlan was more influenced by the thought of H\}ambali, Iln Taymya,Muhammad ibn'Aboul Wahhab, Jamaluddin Al-Afghani, Muhammad 'Aboluh or RashidRida The Salafiyah in their movement in theology, emphasized the necessity of enactment of politics to meet the objectivies of Khilafatstate. Although they wanted to have Khilafat state and feel the significance of politics, this movement did not directly participate in the political practices as other Islamic political parties did in the era of Reformation. Kamarulnizam Abdullah and Mohd Afandi Salleh state:

In the western writings, they are always being referred to as the fundamentalists, militants or radicals. But Muslim scholars tend to disagree with the term since it connotes the idea of radicalism, militancy and negativities. Not all salafis are militants or radicals. There are also salafis that are accommodative or moderate (Abdullah and Salleh, 2015).

Thus, Salafiyah in this sense called "ideological Salafiyah" means Islamic movement which formally struggles for Islamic law characterized by scriptural and firm attitudes and aimstoestablish of Islamic ideology in the form of Islamic Khilafat state, without being directly related to political activities. The ideology of Salafiyah is performed by Majdis Mujahidin Indonesia, Hizbut Tahir Indonesia, or South Sulawesi KPPSI. Given patterns of Salafiyah in Indonesia,we conclude that first, "Traditional Salafiyah" is coincident with Ahl al-Sumah wa'l-Jama'ahand is still related to the thought of Syafi'i, as shown by several pesantrens and O rder groups (Thariqah). Second, "Reformist Salafiyah" or "Modern Salafiyah" is an Islamic movement that aims to return Islam to the original resources, Quranand the Sunnah it rejects any form of tradition, such asshirk, superstition, bidah and khurafat; it brings about Islamic reformation (tajdd fi al-Isam to rise from backwardness and bring changes for better improvements, and it avoid participating in politics, such was initiated by Muhammadyah Al-Irshad, or Indonesian Islamic State.

Third, "Da'wah Salafiyah" or "Jama'ah Salafiyah" is a salafi movement which aims to purify the theology and to model strictly the life of the Prophet and the three generations after, as shown by Salafiyah of Yamani, Haraki, AtTurast, and the Indonesian Forum of Ah al-Sunnah wa'l-Jama'ah led by Ja'far Umar Thalib as well as other similar groups. Fourth, "Ideological Salafiyah" is an Islamic movement carries out formal institutionalization of Islamic law in the life of Muslim communities, including the life of the state and the establishment of Islamic state by referring to the realization of the life of the Prophet and the Islamic caliphates in the modern life, as performed by MMI, HTI, KPPSI, and other communities that were legal-formal, doctrinaire, and militant. Those communities are called by some as "Radical Salafi," "Radical Islam," Islam Radicalism," or "Islamic Fundamentalism". These terms obtained several criticisms in academic discourses and were seen not as the category of Islam but rather as characters or tendencies in understanding and practicing Islam. 
In modern Indonesia, the development of the Islamic thought and movements are numerous. Syafii Anwar, as quoted by Nashir, divided the Islamic thought and movements into six typologies, (1) Formalistic, a legal-formal that emphasizesthe edification and strict observance towards the forms of scriptural or liberal Islamic teachings as well as on the struggle to institutionalize the doctrine and the symbol of teachings in life; (2) Substantivistic emphasizes the meaning of faith and in-depth ritual practices rather than formality and symbols by developing religious attitudes in tolerance to other groups or religions; (3) Transformatic views that the main mission of Islam is to develop partiality, liberation, and Islamic practices in humanity; (4) Totalistic bases the thought on the view of total (kaffah) Islamic doctrine and of containing the insights, values, and guides that were long lasting and complete, including all aspects of human's life; and which applies the elements of fundamentalism in Islam; (5) Idealistic is an Islamic thought and movement that views the importance of Islamic struggles to fulfill the dreams of Ideal Islam that is united to the historical Islam, and (6) Realistic is a thought that looks for the relationship between the substantive dimension of the Islamic doctrines and teachings in the context of the socio-culture of the adherents so that Islamization can face the acculturation (Nashir, 2013).

The development of the Islamic movements, not only in the form of thought, but also appears in the form organized movements in various religious orientations. Among them that are known to represent the religious patterns of revivalist, fundamentalist, or Salafiyahare the movement of Wahhabi (Wahhabiyah) in Saudi Arabia (Abdullah and Salleh, 2015), Ikhwan al-Musimin in Egypt, and Taliban in Afghanistan. Those movements show increasing differences and polarizations that, to some extent, tend to continually politicize Islam in the future.

Traditional Islamic movements, as appeared in Indonesia, especially in the beginning of the twentieth century, in which Nahdhat al-Ulama'was founded in 1926, according to D eliar Noer, indicated a self organization to strengthen the thought and to unite all traditional communities inside or outside the country. Moderate Islamic thought seems to direct the Islamic understanding that is more realistic for Indonesia, by linking the dimension of the substance of the Islamic teachings or doctrines with the social cultural context of the adherents. There are different strategies applied by various Islamic communities in Indonesia. Their movements aim to realize a change. The strategies can be in bottom or top lines. Bottom lines can be seen in the implementation of shar'a in South Sulawesi, Aceh, West Java, and Madura, in which the movement begins from the grassroot levels. Roy called this "bottom-up islamization". As the counterpart, other communities make the changes from the upper line, such asNahdhat al-Ulama'and Muhammadyah The top line deals with the government and bureaucracy in Indonesia (Roy, 1994).

Recently, liberal Islamic movements appeared in Indonesia, tended to be moderate in delivering global religious issues. They were complemented by the emerge of other moderate Islam movements, namely Islamic posttraditionalism, which was led by young generations of Nahdhat al-Ulama'. Their objective is to strengthen moderate Islam in Indonesia, which actually has been organized dominantly by two Islamic movements: Nahdhat al-'Ulama'and Muhammadyah The appearance of moderate Islam (Liberal Islam and Islamic Post traditionalism) isstill relevant to the emerging phenomena of increasingly expressive fundamental-radical movements. Communities that demonstrated some actions, in certain contexts were mostly violent - in the reason of eradication of immorality and protection towards the Muslims from oppression (as happened in Maluku and Poso), showed another image of Indonesian Islam. Unfortunately, other images established by fundamental-radical groups in Indonesia proved to be disadvantageous, especially in the aspect of moderate Islam - whose duties were to break the ice in peaceful, dialogical, and tolerant ways.

\section{Mass media}

In Indonesia, vvarious forms of mass media, such as the television, radio, newspapers, or magazines influence the opinion and belief of individual. Othermedia, such as books are used as references in formal education, are more powerful in building people's ideology or perspective. This media provides a suggestive message that is directs people's opinion. Information on certain issues will provide a new cognitive foundation for certain attitudes towards the information. Strong enough, the suggestive messages become an affective base in assessing certain things. People's religiosity is part of this. Rresearch shows that the content of textbooks used in moderate education institution are generally presented in less vulgar and radical language and doctrine. 
Textbooks used as references are: Al-Qur'an'l-Karim Tafsir Jalalain, Tubfatul-Athfal, Hidayatul-Mustafid AlMuqtatofat, Jawahinu'l-Bukhan, Mustalahu'-Haditly Matan Jami' al Sagir, Dunusul-'Aqaid Tanminul Qulub, Dursu'l-Fiqhiyjah, Al Tahdlib, Kitabưl-Funuq Min Tarikhi al-Tasyi',Dunusu'l-Lughat al-'Arabiygah, Al-Adabu na al Nusus, Khulashah Nunu'lYaqin Taikh al-Daulah al-Ummayjah Wa'l-Abasiyah, Bidayatu'l Mijtahid, Kifayatưl-Akhyar, Riyad al-Salihin, Hikmatu alTadni' Wa falsatuhu, Janahinưl-Kalamiyah, Safinatu al-Najah Taisinu al Tarikh, Al-'Acaid Li'l-Hasan Al-Bamm, Al-Imanu wa al-Khaygat, Rawaidu'l-Bayan, Ilmu Tafsir Suythi, Minhaju'l-Muhit, Al-Takhliyat wa al-Tahdlib, Nasaihu'l-Tbad, al-Tibjan fi Adabi Hamalati'-Qur'an, At-Tahdlib fi Adillati, Minhaju'l-Musim Rawaidu'l-Bayan, Al-Ahkamu al-Sultaniygah IbanaturlAhkam Mau'iz\}du'l-Mưminin, Tafsinu'l-Qur'an li'-Baidhowi, Ahkamu'l Qư'an li'-Imam al-Sjafi'i, Al fighu'l-Isami Waadillatuhu, Syarh Jauharct al-Tauhid, 'Awarifl-Ma'had li Abd'-Qadir, Fathu'l Majid, Husnu'l-Hamidiyjah Jauhanu alTauhid, Al-Luma', Al-Ahkamfi Usali'-Ahkam Usulu'l-Fiqh li'-Khudani, Al-Mustasfa, Al-Usilu fi'l'ilmi'l-Us\}ul, Mabad'ưl'A uwaliysah, Al-Muhadhab, Tuhfatu al-Tullab, Madnahibưl-Anba'ah, Fathul Mưin, Tafsir Maragi,Tafsir Li Baidhavi, Ahkamu'-Qur'anli Imamal-Syafi'i (A hmad Rodli, 2014).

Durukan (2015), based on the works of Elnest Gellner, Harmon Zeigler, Wayne Peak and Janet Maw, writes:

Most theories of nasionalism and education reserve a place for education in general and schooling in particular as tools which introduce the young members of a given society to new sets of worldviews. The selection process of what to teach obviously involves, deliberately or intuitively, ideological convictions as a criterionand the significance of the decision maker(s)is self-evident. In cases of directly state-delivered or even merely state-supervised education, the role of the ruling elites and their ideological outlook comes to the forefront as setting the criteria for deciding on educational content. In the end "all national education systems indoctrinate the oncoming generation with the basic outlooks and values of the political order. In this respect, schools can also be regarded as entities performing political functions that include helping transmit the ideologial norms of the group(s) in power. The importance of schools textbooks, among many others factors within the educational system, is critical because manifest in this picture.Textbooks contain a presentation set of values directly importedto the students trought normal education. Particularly history textbooks are the arena in which the ideology of state is projected and history as a school subject plays an essential role in inculcating or reinforcingnational identity, national consciousness and national values.

A Muslim's religiousity is also determined by how mucha person learns Islamic theology and the history of Islam (tarikh). In learning Islam, history (taikh), in fact, comes in second after theology ('aaidah). Without learning the history, it is difficult for people to understand Islam. O ne of the pillars in Islam is faith in the messengers. No accurate information is to learn the profiles of the messengers, including the Prophet Muhammad but the history of Islam. Similarly, in the learning process, a dichotomy in the subjects of history and hadith exists. All Muslims recognize the apostolate of Prophet Muhammad but only few of them understand the procedures of his religiosity. Radicalism, indeed, emerged from the misunderstanding. In Islamic formal education, such as pesantren, history of Islam (sirah nabawiygah), as well as authentic traditions (hadth) and summah of the prophet are intensely studied. From the subjects learned and the textbooks used in peantrens the text books on history and the subject of the history of Islamic culture are in equal number compared to the subjects and text books related to theology.

According to Amin Abdullah, to clearly outlook Islamic phenomena in contemporary Indonesia, Muslims should not directly jump to the 19th and 20th century. Culturally, they need to look far backward, to the 15th, 16th, and 17th. There is continuity in the cultural heritage and in the way of thinking among the generations that is unable to cut off. Culture is the way of thinking; view of life, philosophy, world view, and religious perspective that generally form daily behavior in many aspects of human's life (2000).

Literature on spiritual emerged in the 15th and 16th centuries were sufistic. Experts state that philosophical attitude isthe one that avoids conflict, open criticism, social protests, and encourage self-reflection that refers to concord and harmony. Literature on Javanese Islam is the prototype of the 18th. By generally observing the sufistic literatures in the middle century, diversity in personal piety is seen to appear in the fundamental structure of sufistic thoughts. Works of Ima>mal Gheza>li>, which are considered by Mohammed Ahmed Sharif become main source of the concept for sufistic religiosity in the middle centuris (Abdullah, 2000), are read by many Indonesian Muslims, especially students in pesantrens

\section{Conclusions}

Moderate Muslim dominates various regions in Indonesia. It is directly understood as passive but is more expressive in responding the differences and government policies. 
The domination of moderate thought survives in Indonesia because of iteasily adapts to an culture. It is different from radical religiosity that is usually confrontational and firm in facing new tradition. In addition, moderate Muslim occupies strategic positions in the governments, either formal organization (that is more secular) or religious organizations, such as Majeis Ulama Indanesia (The Ulama Council of Indonesia). Formal education has similar formation. This intense cooperative becomes the media to strengthen both position of the government and the community of the moderate Islam.

Moderate Islam has been used to face foreign traditions. In religious formal education, such as madrasahand pesantren, the students learn various religions and diverse perspectives of the 'ulam. Differences are common in the subject of Islamic religion in religious education in Indonesia. Similarly, references used by the students contain explanation on the various perspectives of religion. Therefore, when the students encounter different perspectives both radical and liberal, moderate Islam believers can establish a good relationship between social and religion. There is no instruction to eliminate the followers of radical and liberal Islam by moderate Muslims. Indeed, a dialogical aspect needs to be improved and social interest should be prioritized.

\section{References}

Abdullah, Amin. (2000).Dinamika IdamKultural, PemtaanatasWacama Keisaman Kontemparer. Bandung: Mizan.

Abdullah, Kamarulnizam\&Afandi Salleh, Mohd. (2015), "Conceptualizing Jihad Among Southeast Asia's Radical Salafi Movements,"Jaumal for theStudy of RedigionsandIdedogies 14, 42.

Ali, Fachry \&Bahtiar Effendi. (1986).MerambahJalan BaruIsam Bandung: Mizan.

Ali, Fachry. (1991)."Akomodasi Non-Politik Islam Indonesia dalam Struktur O rdeBaru."Prisma.

Aminudin. (1999).Kdkuatan Isam dan Pegulatan Kdkuasaan d Indonesia Sebdum dan sesudah Runtuhnya Rerim Sodharto Yogyakarta: Pustaka Pelajar.

Anwar, M. Syafii. (1992). “Islam, Negara dan Formasi Sosial dalam O rde Banu.” Jumal 'Ulumul QuranIII, 3.

Arskal \& Azyumardi Azra (eds.). (2003). "Introductioan: The State and Shari>'ain Perspective of Indonesian Legal Politics" Shari'a and Pditics in Modem Indoneian, edited byArskal \&Azyumardi Azra. Singapore: Insitut of Southeast A sian Studies.

Barker, Chris. (2000).Cultural Studies, TherryandPradice London: Sage Publications.

D urukan, S. Akile Zorlu. (2015). "The Religion of Muhammad": Early Turkish Republican Ideology and The Official View of Islam In 1930s History Textbooks,"Jamal for theStudy of ReigiausandIdedoges 14, 41.

Effendy, Bahtiar. (2001). MasyarakatAgama dan PluralismeKeagamaan Y ogyakarta: G alang Press.

Effendy, Bahtiar. (2003).Isamand TheStatein Indonesia Singapore: ISEAS.

Esposito, John L., (ed.). (1995).TheOxfordEngdqpedia of theModknISlamidodd New Y ork: O xfordUniversity Press.

Gaffar, Affan .(1993). “Islam dan Politik dalam Era O rde Baru:Mencari Bentuk Artikulasi yang Tepat,” Jumal Ulumul Quran2, IV.

Geertz, C. (1968).IsamObseved Reigiaus Dexdqument in Marocoand IndonesiaChicago: University of Chicago Press.

Graham, William A. (1993). "Traditionalism in Islam: An Essay in Interpretation", Jaumal of Intediscipinary Histary23, 3.

Hall, Calvin S. at al. (1978). Theenes of Persanality. New Y ork: Santa Barbara.

Hall, S. (ed.). (1997). "The Work of Representation” Represtation London:Sage.

Hefner, W. Robert. (1995).ICMI dan Pejuangan MenujuKdas Menengah Indanesia Y ogyakarta: Tiara Wacana.

Hodgson, M.G. (1975). TheV ettureOfIsam Chicago: Universityof Chicago Press.

Horikoshim. (1987). Kiai dan Peubahan Sosial. Jakarta: P3M.

Johns , Anthony H. (1987). "Indonesia:Islam and Cultural Pluralism," In John L. Esposito, (ed.), Isamin Asia, Rdigion, Pditics\& Soidy. New Y ork: Oxford University Press.

Kuntowijoyo.(1996). "Tiga Strategi Pergerakan Islam: Struktural, Kultural dan Mobilitas Sosial," Dimamika Pemikiran Isamdan Muhammadiyah ed., Nurhadi M. Musawir. Y ogyakarta: Lembaga Pustaka dan D okumentasi Pimpinan Pusat Muhammadiyah.

Kuntowijoyo.(1994). Dinamika Sgarah Unat IsamIndanesia Y ogyakarta: Shalahuddin Press dan Pustaka Pelajar. Kurzman, Charles, (ed.). (1998).Libeal Islam A Sarcdook. New Y ork: O xfordUniversity Press. 
Mahasin, Aswab. (1993). "Kelas Menengah Santri: Pandangan dari Dalam," Pditik Kdas Menengah Indonesia, eds., Richard Tanter dan Kenneth Young. Jakarta: LP3E S.

Mujiburrahman. (2006). FeelingThreatened MusimChrisianin Indonesa's NewOrdar. Leiden: Amsterdam University Press. Nashir, Haedar. (2013).IsamSyan'at Reproduks SalafiyahIdedogisdi Indonesia Bandung: Mizan.

Nasr, Seyyed Hossein. (1987). TraditionIsamin theModanW orld. London: KPI.

Noor, Firman. (2007). "Moderat Islamic Fundamentalism: Understanding the Political Thinking of the Partai Keadilan Sejahtera (PKS)," Studa Idamika, IndonesianJarmal for Idamic Studes 14, 3.

Pals, D aniel L.. (1996).Sean Theries of Reigion New York: OxfordUniversity Press.

Richard, C. (1997). Defendas of ReasoninIslam. Oxford: Oneworld, 1997.

Ridwan, Nur K holik.(2009). NU dan Neeliberalisme Y ogyakarta: LKiS.

Rodli, A hmad. (2014).Epistemdog dan Idelog Pendidkan Pesantren (Stud KunikulumPesantren Krapyak Yograkarta Indonesia dengan Ponddk Pasir Tumboh Klantan Malaysia).Y ogyakarta: Lembaga Penelitian dan Pengabdian Masyarakat UIN Sunan Kalijaga.

Roy, O liver. (1994). TheFailure of Pditical Islam. London: T.B. Tauris Publishers.

Sharif, Mohammed Ahmed. (1975). Ghezali's Thery of Virtue Albany: StateUniversity of New Y ork Press.

Taher, Tarmizi. (1998). Meriju Ummatan Wasathan, Keukunan Beragama di Indonesa Jakarta: PPIM Jakarta.

Turner, Bryan S. (2011).Rdigion and Modm Socidy, Citizendip Seulanisation and the State New York: CambridgeUniversity Press. 